\title{
Determination of Safe Duration of Exposure to Benzene at Public Gas Stations Around Diponegoro University Semarang, Indonesia
}

\author{
Genduk Lintang Rusmawarda ${ }^{1}$, Abdul Rohim Tualeka', Dimas Triyadi², Pudji Rahmawati ${ }^{3}$, Syamsiar S \\ Russeng ${ }^{4}$, Atjo Wahyu ${ }^{4}$, Ahsan ${ }^{5}$ \\ ${ }^{1}$ Department of Occupational Safety and Health, Faculty of Public Health, Airlangga University, 60155 \\ Surabaya, East Java, Indonesia; ${ }^{2}$ Department of Environmental Health, Faculty of Public Health, \\ Diponegoro University, Semarang, Indonesia; ${ }^{3}$ Department of Development of Islamic Society, State \\ Islamic University Sunan Ampel, Surabaya, Indonesia; ${ }^{4}$ Department of Occupational Safety and Health, \\ Faculty of Public Health, Universitas Hassanudin, Makassar, Indonesia; ${ }^{5}$ Faculty of Nurse, University of \\ Brawijaya, Malang, Indonesia
}

\begin{abstract}
Benzene in the air can be found from emissions of coal and oil combustion, gas stations, and motor vehicle workshops. This research was descriptive, observational, and cross sectional and aimed to determine safe duration of exposure (Safe Dt) to benzene for officers of the public gas stations around the area of Diponegoro University Semarang. The subjects of this research were 28 officers determined by Slovin formula and proportional random sampling and taken by purposive sampling technique according to the inclusion criteria of the researchers. The variables of this research were animals weight, BSA experimental animals, officers weight, Body Surface Area, officers breathing rate, benzene concentration, Animal Km, Human Km, NOAEL, officers RfC, and Safe Dt.

The average concentration was $0.25 \mathrm{ppm}$ and the highest concentration was $2.08 \mathrm{ppm}$. From the comparison of results and the Threshold Limit Value according to Permenakertrans No.5/MEN/X/2018, there is still a need for efforts to control benzene exposure by companies and governments, such as determining the period of service of officer who refers to the calculation of safe duration of exposure (Safe Dt) to benzene by 2.2 years. In addition, efforts to control benzene exposure can be also performed by providing Personal Protective Equipment (PPE), i.e half mask respirator with an organic vapor cartridge for officers and regular monitoring of benzene exposure in the work environment.
\end{abstract}

Keywords: Benzene, public gas stations, duration of safe exposure

\section{Introduction}

Benzene in the air is resulted from emissions of coal and oil combustion, gas stations, and motor vehicle workshops. Chronic benzene exposure or long term inhalation can cause various circulatory disorders, including reduced red blood cells and aplastic anemia.

\section{Corresponding Author:}

Abdul Rohim Tualeka

Department of Occupational Safety and Health, Public Health Faculty, Airlangga University, 60115, Surabaya, East Java, Indonesia

Phone: +62-31-592-0948

Email: abdul-r-t@ffkm.unair.ac.id
The Environmental Protection Agency (EPA) classifies carcinogenic benzene for humans through various exposure routes $^{(2)}$.

The level of exposure to benzene at gas stations in low and middle income countries according to Navasumrit et al. (2005) and Bahrami et al. (2007) in IARC 
Monographs showed higher concentrations of benzene ${ }^{(3)}$. Severity of poisoning caused by benzene depends on concentration, route, and duration of exposure, as well as age and medical conditions of the exposed person ${ }^{(4)}$. Benzene compounds as solvents have the value of the Inhalation Reference Concentration (RfC) and Cancer Slope Factor (CSF) that have been determined by the US Environmental Protection Agency's Integrated Risk Information System (IRIS U.S. EPA) in 2003. The value of Inhalation Reference Concentration (RfC) for noneffect carcinogenic $3 \times 10-2 \mathrm{mg} / \mathrm{m}^{3}$ converted to 0.0086 $\mathrm{mg} / \mathrm{kg}$ /day and the Cancer Slope Factor (CSF) value for a carcinogenic effect of $2.2 \times 10^{-6}-7,8 \times 10^{-6} \mathrm{mg} / \mathrm{m}^{3}$ which is converted to $0,1-0,34 \mathrm{mg} / \mathrm{kg} / \mathrm{day}^{(5)}$.

Exposure to benzene which can be tolerated by the European Chemicals Agency (ECHA) is 1 ppm or converted to $3.25 \mathrm{mg} / \mathrm{m}^{3(6)}$. The National Institute for Occupational Safety \& Health states the Recommended Exposure Level (REL) of benzene which can be tolerated at $0.1 \mathrm{ppm}$ or if converted to $0.32 \mathrm{mg} / \mathrm{m}^{3(7)}$. Whereas according to the Committee for Hazardous Substances in Germany, benzene exposure can be tolerated at 1.9 $\mathrm{mg} / \mathrm{m}^{3(8)}$. Indonesia itself regulates the safe limits of benzene exposure concentrations in Permenakertrans No.5/MEN/X/2018 in 2018. The Threshold Limit Value (TLV) of benzene is $0.5 \mathrm{ppm}^{(9)}$.

Central Java is a province with the third largest population estimate in Indonesia in $2013^{(10)}$. Semarang has the highest population growth rate compared to other cities or districts in $2010-2017$ by $1.72 \%$ caused by the existence of several universities $^{(11)}$. In 2013, this affects the number of motorized vehicle use in Banyumanik and Tembalang subdistricts which reached 5,707 and 16,221 units $^{(12)}$. Ministerial Decree Number 1585/K/32/ MPE/1999 concerning the gradual elimination of lead $(\mathrm{Pb})$ and substitution with benzene does not reduce the carcinogenic effects of fuel ${ }^{(13)}$. Public gas stations officers have a high level risk of benzene exposure because they exposed to hazardous chemicals for years of work.

Based on the results of research by Costantini et al. (2003) and Paci et al. (1989) in Agency for Toxic Substances and Disease Registry (2007), shoe factory workers in Italy showed an increased risk of leukemia along with increased benzene exposure. International Agency for Research on Cancer (IARC) and the Environmental Protection Agency (EPA) Weight of Evidence for Carcinogenicity (WOE) in 2005 under
U.S. The Environmental Protection Agency classifies benzene in Category 1 (carcinogenic) and $\mathrm{CH}$ (carcinogenic to humans) ${ }^{(14)}$. The risk of cancer or other health problems due to exposure to benzene to humans is clearly dangerous so it is necessary to calculate the safe duration of exposure to workers exposed to benzene in the work environment.

Previous research has not calculated the safe duration of exposure (Safe Dt) using either RfC formula with No Observed Adverse Effect Level (NOAEL) for workers exposed to benzene when working. Public gas stations officers are one of the jobs with a high risk of benzene exposure so that the calculation of Safe Dt is important to reduce the risk of cancer and other health problems due to benzene exposure ${ }^{(18)}$. Safe Dt to benzene is best calculated using RfC formula with NOAEL adjusting the research data so as not to cause harmful effects on the body ${ }^{(19)}$. Therefore, the authors calculated Safe Dt to benzene using RfC formula with NOAEL as the safe limit for the duration of benzene exposure for public gas stations officers.

\section{Material and Method}

This research was a descriptive, observational, and cross sectional which aimed to determine safe duration of exposure (Safe Dt) to benzene. The population of this research was 78 officers of the public gas stations around Diponegoro University Semarang. 28 officers were taken as samples taken by purposive sampling technique according to the inclusion criteria of the researchers.

Data were taken in the form of primary data obtained through filling out questionnaires, weighing the body, and measuring benzene intake officers of the public gas stations with personal dust sampler and coconut shell charcoal as well as secondary data such as the number of officers, years of service, type of fuel, work shift schedules, and weight of experimental animals. The variables of this research includes animals weight, BSA experimental animals, officers weight, officers body surface area, officer breathing rate, benzene concentration, Animal Km, Human Km, NOAEL, reference concentration of benzene on the officer, and safe duration of exposure (Safe Dt) to benzene in the air for officers. Analysis of research data to determine safe duration of exposure to benzene was carried out manually. 


\section{Findings}

A. Characteristics and Bodies Surface Area of Experimental Animal: The toxicity test using animals as a model aims to see the existence reactions in humans against a test substance. The experimental animals used in this research were white mice (Rattus Norvegicus) ${ }^{(20)}$.

Table 1: Distribution of Characteristics of White Mice

\begin{tabular}{|c|c|c|}
\hline $\begin{array}{c}\text { Experimental } \\
\text { nimal (White rat) }\end{array}$ & $\begin{array}{c}\mathbf{W} \\
\mathbf{( k g )}\end{array}$ & $\begin{array}{c}\text { BSA } \\
\mathbf{( m}^{\mathbf{2}}\end{array}$ \\
\hline 1 & 0,1405 & 0,024165 \\
\hline 2 & 0,1405 & 0,024165 \\
\hline 3 & 0,1410 & 0,024223 \\
\hline 4 & 0,1410 & 0,024223 \\
\hline 5 & 0,1395 & 0,024050 \\
\hline 6 & 0,1415 & 0,024165 \\
\hline
\end{tabular}

The surface area of white mice is calculated by using the following formula.

$\mathrm{BSA}=0,09 \mathrm{~W}^{0,67}$

Where,

BSA: Body Surface Area $\left(\mathrm{m}^{2}\right)$

W: Weight $(\mathrm{kg})$

B. Characteristics, Body Surface Area, and Respiratory Rate of Officers: The samples of this research have characteristics with an average body weight of $58.57 \mathrm{~kg}$ and an average length of time working 6.5 hours/day. In this research, the average height used was the average Indonesian male height of $159 \mathrm{~cm}$.

\section{Body surface area}

$B S A=\bigvee_{W} \cdot \mathrm{h} / 3600$

Where,

BSA: Body Surface Area $\left(\mathrm{m}^{2}\right)$

W: Weight $(\mathrm{kg})$

h: Height (cm)

$$
\begin{aligned}
\mathrm{BSA} & =\sqrt{\mathrm{W} \cdot h / 3600} \\
& =\sqrt{58,57 \cdot 159 / 3600} \\
& =1,6 \mathrm{~m}^{2}
\end{aligned}
$$

\section{Breathing rate}

$$
\mathrm{BR}=\frac{5,3 \ln \mathrm{W}-6,9}{24}
$$

Where,

BR : Breathing Rate $\left(\mathrm{m}^{3} /\right.$ hour $)$

W : Weight ( $\mathrm{kg})$

$$
\begin{aligned}
\mathrm{BR} & =\frac{5,3 \ln \mathrm{W}-6,9}{24} \\
& =\frac{5,3 \ln 58,57-6,9}{24} \\
& =0,6 \mathrm{~m}^{3} / \mathrm{jam}
\end{aligned}
$$

\begin{tabular}{|c|c|c|c|c|c|}
\hline $\begin{array}{c}\text { Number } \\
\text { of } \\
\text { sample }\end{array}$ & $\underset{\mathbf{k} \sigma)}{\mathbf{W}}$ & $\begin{array}{c}\text { h } \\
(\mathrm{cm})\end{array}$ & $\begin{array}{l}\text { BSA } \\
\left(\mathrm{m}^{2}\right)\end{array}$ & $\begin{array}{c}\text { BR }\left(\mathbf{m}^{3} /\right. \\
\text { hour })\end{array}$ & $\begin{array}{c}\text { t } \\
\text { (hour/ } \\
\text { day) }\end{array}$ \\
\hline 28 & ו & 159 & 1,0 & 0,0 & 6,5 \\
\hline
\end{tabular}

Table 2: Distribution of Characteristics, Respiratory Rate, and Duration of Work of public gas stations officers around Diponegoro University Semarang

C. Benzene Concentration: The average concentration of benzene in exposed air in public gas stations around Diponegoro University Semarang is $0.82 \mathrm{mg} / \mathrm{m}^{3(15)}$ or $0.25 \mathrm{ppm}$.

$\mathrm{C}=24,45 \times \mathrm{C}\left(\mathrm{mg} / \mathrm{m}^{3}\right) \div$ molecular weight

$\mathrm{C}=24,45 \times \mathrm{C}\left(\mathrm{mg} / \mathrm{m}^{3}\right) \div$ molecular weight

$$
\begin{aligned}
& =24,45 \times 0,82 \mathrm{mg} / \mathrm{m}^{3} \div 78,11 \\
& =0,25 \mathrm{ppm}(<0,5 \mathrm{ppm})
\end{aligned}
$$

\section{Animal Km dan Human Km}

\section{Animal Km}

Animal $\mathrm{Km}=\frac{\mathrm{W} \text { animal }}{\mathrm{BSA} \text { animal }}$

Where,

Animal $\mathrm{Km}: \mathrm{Km}$ factor in experimental animals

W : Weight $(\mathrm{kg})$

BSA : Body Surface Area $\left(\mathrm{m}^{2}\right)$

Table 3: Animal Km in White Mice

\begin{tabular}{|c|c|c|c|}
\hline $\begin{array}{c}\text { Experimental } \\
\text { animal } \\
\text { (White mice) }\end{array}$ & $\begin{array}{c}\mathbf{W} \\
\mathbf{( k g )}\end{array}$ & $\begin{array}{c}\text { BSA } \\
\left.\mathbf{( m}^{\mathbf{2}}\right)\end{array}$ & $\begin{array}{c}\text { Animal Km } \\
\mathbf{( W / B S A )}\end{array}$ \\
\hline 1 & 0,1405 & 0,024165 & 5,814194082 \\
\hline 2 & 0,1405 & 0,024165 & 5,814194082 \\
\hline 3 & 0,1410 & 0,024223 & 5,820914007 \\
\hline 4 & 0,1410 & 0,024223 & 5,820914007 \\
\hline
\end{tabular}


Conted...

\begin{tabular}{|c|c|c|c|}
\hline 5 & 0,1395 & 0,024050 & 5,8004158 \\
\hline 6 & 0,1415 & 0,024165 & 5,855576247 \\
\hline Average & 0,1407 & 0,024165 & 5,82 \\
\hline
\end{tabular}

\section{Human Km}

$$
\text { Human } \mathrm{Km}=\frac{\text { W human }}{\text { BSA human }}
$$

Table 4: Human Km of Public Gas Stations Officers around Diponegoro University Semarang

\begin{tabular}{|c|c|c|c|}
\hline $\begin{array}{c}\text { Number of } \\
\text { sample }\end{array}$ & $\begin{array}{c}\text { W } \\
(\mathbf{k g})\end{array}$ & $\begin{array}{c}\text { BSA } \\
\text { (m2) }\end{array}$ & $\begin{array}{c}\text { Human Km } \\
\text { (W/BSA) }\end{array}$ \\
\hline 28 & 58,57 & 1,6 & 36,6 \\
\hline
\end{tabular}

E. No Observed Adverse Effect Level (NOAEL):

Swaen et al (2010) stated that the calculation of No Observed Adverse Effect Level (NOAEL) benzene was $3.0 \mathrm{mg} / \mathrm{m}^{3}$ or equivalent to $0.022 \mathrm{mg} /$ $\mathrm{kg}$ obtained by using the following formula ${ }^{(21)}$.

NOAEL benzene $=3,0 \mathrm{mg} / \mathrm{m}^{3}$

$$
\begin{aligned}
\text { NOAEL benzene } & =\frac{3 \times 0,00013 \times 8}{0,1405} \\
& =0,022 \mathrm{mg} / \mathrm{kg}
\end{aligned}
$$

\section{F. Inhalation Reference Concentration (RfC):} Shaw et al. (2007) in the 2013 Industrial Toxicology \& Risk Assessment book stated that the calculation of inhalation RfC can use the following formula ${ }^{(22)}$.

$$
\mathrm{RfC}=\mathrm{NOAEL} \frac{\text { animal } \mathrm{Km}}{\text { human } \mathrm{Km}}
$$

Where,

Animal Km : Km factor on animal

Human $\mathrm{Km}: \mathrm{Km}$ factor on human

Inhalation RfC obtained from the NOAEL value, the average Animal Km, and the average Human $\mathrm{Km}$ are as follows.

$$
\begin{aligned}
\text { RfC } & =\text { NOAEL } \frac{\text { animal Km }}{\text { human Km }} \\
& =0,022 \frac{5,82}{36,6} \\
& =0,003 \mathrm{mg} / \mathrm{kg}
\end{aligned}
$$

G. Safe Duration of Exposure (Safe Dt) to Benzene: Control of non-carcinogenic and carcinogenic risks can be performed by determining the safe limits of exposure to hazardous chemicals for officers, one of which is by determining the duration of safe exposure associated with the duration of work and working period ${ }^{(23)}$.

Safe $\mathrm{Dt}=\frac{\mathrm{R} f \mathrm{C} \times \mathrm{W} b \times t \text { avg }}{\mathrm{C} \times \mathrm{BR} \times t \mathrm{E} \times f \mathrm{E}}$

Where,

Safe Dt : Safe duration of exposure for officers (years)

RfC : Inhalation Reference Concentration (mg/ $\mathrm{kg})$

$\mathrm{Wb}:$ Weight $(\mathrm{kg})$

$\mathrm{t}$ avg : Average of time (day)

$\mathrm{C}:$ Konsentrasi di udara $\left(\mathrm{mg} / \mathrm{m}^{3}\right)$

$\mathrm{BR}$ : Breathing Rate $\left(\mathrm{m}^{3} /\right.$ hour$)$

tE : Duration (hour/day)

$\mathrm{fE}:$ Frequency of Exposure (day/year)

Safe Dt $=\frac{0,0003 \times 58,57 \times 30 \times 65}{0,82 \times 0,6 \times 6,5 \times 267,43}=2,2$ years

The average concentration of benzene in the air exposed to samples was $0.82 \mathrm{mg} / \mathrm{m}^{3}(0.25 \mathrm{ppm})$. From the total measurement of benzene concentration, the highest was $2.08 \mathrm{ppm}^{(15)}$. The average value of this concentration is lower than the TLV, yet the highest concentration value far exceeds the TLV of $0.5 \mathrm{ppm}$ according to Permenakertrans No.5/MEN/X/2018. Toxicity test was carried out by using NOAEL as the determination of the highest dose of toxin without causing an effect. Based on the results of these studies, the benzene NOAEL value of Rattus norvegicus was $0.022 \mathrm{mg} / \mathrm{kg}$. This value is in accordance with the results of a research by Swaen et al. (2010) with NOAEL benzene value of $3.0 \mathrm{mg} /$ $\mathrm{m}^{3}$ or equivalent to $0.022 \mathrm{mg} / \mathrm{kg}^{(21)}$. The NOAEL value obtained was smaller than that of the 2005 Agency for Toxic Substances and Disease Registry (ATSDR) of 3 ppm at medium exposure through inhalation ${ }^{(1)}$.

Based on the results of RfC calculation, NOAEL value, average Animal $\mathrm{Km}$ and Human $\mathrm{Km}$ was 0.003 $\mathrm{mg} / \mathrm{kg}$. The RfC of this research was smaller than the value set by IRIS U.S The EPA in 2003 of $0.03 \mathrm{mg} / \mathrm{m}^{3}$ 
$(0.0085 \mathrm{mg} / \mathrm{kg} / \mathrm{hr})^{(5)}$. Apart from being smaller than IRIS U.S. EPA, the result of this research was also smaller than the research conducted by Hayat (2013) by 0.0086 $\mathrm{mg} / \mathrm{kg} / \mathrm{day}^{(17)}$ and research conducted by Salim (2012) by $0.01 \mathrm{mg} / \mathrm{kg} / \mathrm{hr}^{(16)}$. Thus, the result of this research was safer for humans.

Based on the results of the calculations, the value of Safe Dt to benzene at the public gas stations around Diponegoro University Semarang was 2.2 years. This is smaller than the average duration of public gas stations officers exposure of 5.5 years. In addition, the Law of the Republic of Indonesia No. 13 of 2003 concerning Labor states that the maximum time limit for hiring employees is 3 years $^{(24)}$. This indirectly provides protection so that public gas stations officers are not exposed to benzene for much longer.

\section{Conclusion}

Measurement of the concentration of benzene at public gas stations around Diponegoro University Semarang resulted in an average concentration of 0.25 ppm and the highest concentration of $2.08 \mathrm{ppm}$. The average value of the concentration is lower than the Threshold Limit Value, yet the highest concentration value far exceeds the Threshold Threshold Limit Value of $0.5 \mathrm{ppm}$ according to Permenakertrans No.5/ MEN/X/2018. Therefore, there are still efforts need to be taken to control benzene exposure by companies and governments to keep officers healthy.

One of the efforts to control benzene exposure is determining the working period of officers, which refers to the calculation of benzene safe exposure, reduces the concentration of toxins to the safe limits of toxin concentration for officers, and reduces exposure time per day by $<8$ hours/day. Calculation Safe Dt to benzene for non-carcinogenic risks to public gas stations officers around Diponegoro University Semarang resulted in 2.2 years. In addition, efforts to control benzene exposure can be performed by providing Personal Protective Equipment (PPE) in the form of half mask respirators with organic vapor cartridges and periodic monitoring of benzene exposure in the work environment.

Conflict of Interest: All authors have no conflicts of interest to declare.

Source of Funding: This is an article "Determination of Safe Limits Exposure Duration to Benzene at Public
Gas Stations around Diponegoro University Semarang" of Occupational Safety and Health Department that was supported by Activity Budget Plans 2019, Faculty of Public Health, Airlangga University.

Ethical Clearance: The research was approved by the institutional Ethical Board of the Public Health Faculty, Diponegoro University.

\section{REFERENCES}

1. Agency for Toxic Substances and Disease Registry. Toxicological Profile for Benzene. ATSDR's Toxicological Profiles. Atlanta: Division of Toxicology and Environmental Medicine; 2007.

2. National Center for Environmental Assessment. Benzene. Washington DC: U.S. Environmental Protection Agency; 2012. 1 p.

3. Lyon F. IARC Monographs Benzene. 2018;120(October 2017):10-7.

4. Centers of Disease Control and Prevention (CDC). Facts About Benzene [Internet]. CDC. 2018. Available from: https://emergency.cdc.gov/ agent/benzene/basics/facts.asp.

5. IRIS U.S EPA. Benzene ; CASRN 71-43-2. 2003;1-43. Available from: https://cfpub.epa. gov/ncea/iris $2 /$ chemicalLanding.cfm?substance_ $\mathrm{nmbr}=276$.

6. The European Parliament and The Council of The European Union. DIRECTIVE 2004/37/EC, 29 April 2004. Off J Eur Communities. 2000;L 269(September 2000):1-15.

7. National Institute for Occupational Safety \& Health. NIOSH pocket guide to chemical hazards. DHHS (NIOSH) Publication. 2010. p. 168.

8. Germany Federal Institute for Occupational Safety and Health (BAuA). The risk-based concept for carcinogenic substances developed by the Committee for Hazardous Substances. 1st ed. Paderborn: Federal Institute for Occupational Safety and Health (BAuA); 2013.

9. Menteri Ketenagakerjaan Republik Indonesia. Peraturan Menteri Ketenagakerjaan Republik Indonesia Nomor 5 Tahun 2018. 2018.

10. Pusat Data dan Informasi. Ringkasan Eksekutif Data dan Informasi Kesehatan Provinsi Jawa Tengah. Jawa Tengah; 2013. 
11. BPS Provinsi Jawa Tengah. Jumlah Penduduk dan Laju Pertumbuhan Penduduk Menurut Kabupaten/ Kota di Provinsi Jawa Tengah, 2015, 2016, dan 2017 [Internet]. Indonesia Population Projection 2010-2025. 2018. Available from: https://jateng. bps.go.id/statictable/2017/10/26/1533/jumlahpenduduk-dan-laju-pertumbuhan-pendudukmenurut-kabupaten-kota-di-provinsi-jawatengah-2015-2017.html.

12. BPS Kota Semarang. Banyaknya Kendaraan Bermotor dirinci menurut Jenis Kendaraan, 2012 - 2014 [Internet]. BPS Kota Semarang. 2014. Available from: https://semarangkota.bps.go.id/ linkTableDinamis/view/id/23.

13. Menteri Pertambangan dan Energi. Keputusan Menteri Pertambangan dan Energi Nomor 1585 K/32/MPE/1999. 1585 Jakarta; 1999 p. 1-2.

14. US EPA. Table Prioritized Chronic Dose-Response Values for Screening Risk Assessments. 2008.

15. Triyadi D, Nurjazuli, Dangiran HL. Analisis Risiko Kesehatan Akibat Paparan Benzene Melalui Inhalasi Pada Petugas Stasiun Pengisian Bahan Bakar Umum (SPBU) di Sekitar Kawasan Universitas Diponegoro Semarang. Kesehat Masy. 2016;4:907-16.

16. Salim RN. Analisis Risiko Kesehatan Pajanan Benzena Pada Karyawan di SPBU " $x$ " Pancoranmas Depok. Fakultas Ilmu Kesehatan, Universitas Indonesia. Universitas Indonesia; 2012.

17. Hayat I. Paparan Benzena Pada Petugas Operator Spbu Di Wilayah Ciputat Tahun 2012. Universitas Islam Negeri Syarif Hidayatullah Jakarta; 2013.
18. Tualeka AR, Pathak Y, Wibrata DA, Ilmi B, Ahsan A, Rahmawati P, et al. Relationship of Benzene Exposure to Trans, Trans-Muconic Acid and Blood Profile of Shoe Workers in Romokalisari Surabaya, Indonesia. Open Acces Maced J Med Sci. 2019;7(5):816-23.

19. TualekaAR,FaradishaJ, Maharja R.Determination of No Observed Adverse Effect Level Ammonia in White Mice Through CD4 Expression. DoseResponse An Int J. 2018;16(4):1-9.

20. Badan Pengawas Obat dan Makanan (BPOM). Peraturan Kepala Badan Pengawas Obat dan Makanan Republik Indonesia Nomor 7 Tahun 2014. Jakarta; 2014 p. 561-5.

21. Swaen GMH, Amelsvoort L Van, Twisk JJ, Verstraeten E, Slootweg R, Collins JJ, et al. Low Level Occupational Benzene Exposure and Hematological Parameters. Chem Biol Interact. 2010;184(1-2):94-100.

22. Tualeka AR. Toksikologi Industri \& Risk Assessment. Surabaya: Graha Ilmu Mulia; 2013.

23. Tualeka AR, Zuhro R, Harsetianingrum RA. Determination of The Safe Duration of Benzene Non Carcinogenic Exposure in Motor Workshop Area. Indian J Public Heal Res Dev. 2018;9(11):582.

24. Presiden Republik Indonesia. Undang-undang Republik Indonesia Nomor13 Tahun 2003 Tentang Ketenagakerjaan. 2003. 